\title{
CENGİZ HAN OĞLU TOLUY I: AİLESİ
}

\author{
GENGHIS KHAN'S SON TOLUI I: FAMILY
}

Burak ÇELIK**

\begin{abstract}
$\ddot{O} z$
Cengiz Han'ın en küçük oğlu Toluy, Orta Çă̆ tarihçilerinin kendinden en az bahsettiği prens olmasına rağmen yaşadı̆̆ı dönemdeki faaliyetleri ve öldükten sonra arkasında bıraktı̆̆ı mirasıyla imparatorluğun büyümesine Cengiz Han oğulları arasında en fazla etki ettiğgi düşünülen kişidir. Cengiz Han'ın baş hatunu Börte Uçin'den doğan son oğlu Toluy'un Sorgaktani Beki adlı baş hatunu ile birlikte altı hatunu, on oğlu, üç kızı ve yüzlerce torunu vardır. Toluy Cengiz Han'ın ölümünü müteakip 1227-1229 yılları arası iki yıl saltanat naipliği yapmasına rağmen Büyük Han unvanı kazanamamıştır. Ancak öldükten sonra çocukları otuz yıl içinde neredeyse bütün Moğol Hanlı̆̆ının tek hâkimi haline gelmiştir. İkisi şube Moğol Devleti, diğeri Karakorum'daki büyük hanlık tahtını elde etmiş, Moğolların siyasi yaşamma doğrudan tesirde bulunmuş üç büyük şahsiyet; Mengü, Kubilay ve Hulâgû'nun babasıdır. Bununla birlikte Toluy'un diğer eş ve cariyelerinden doğmuş üvey çocuklarından Möge, torunlarından Tok Temür ve Kelmiş Aka'nın Moğolların iç ve dış siyasetinde güçlü etkileri görülmektedir. Yasal ve üvey bütün Toluy oğullarının kendilerine kalan mirasın yanında nitelikli birer hükümdar gibi yetiştirilmelerinde, onlarm eğitimleriyle ayrım gözetmeksizin ilgilenen baş hatun Sorgaktani Beki'nin önemli bir rolü vardır. Üç çalışmadan oluşacak makale dizisinin birinci bölümü olan bu çalışmada Toluy'un ailesi bütünlük içinde tanıtılmaya çalışılarak, Toluy ailesinin Moğol iç ve dış siyasetindeki etkileri anlatılmaya çalışılmıştır.
\end{abstract}

\section{Anahtar Kelimeler}

Moğollar, Toluy, Sorgaktani Beki, Toluy oğulları, aile, hatun

\begin{abstract}
Although he was the least mentioned prince by medieval historians, Genghis Khan's youngest son Tolui is thought to have had the most influence among the sons of Genghis Khan on the growth of the empire with his activities during his life and legacy he left behind after his death. Tolui, the last son of Genghis Khan born from Genghis Khan's chief wife Börte Ujin, has six wives including his chief wife named Sorghaghtani Beki, ten sons, three daughters and hundreds of grandchildren. Tolui did not gain the title of Great Khan, although he was a regent for two years between 1227 and 1229 following the death of Genghis Khan. After his death, however, his children became the absolute rulers of nearly the entire Mongol Khanate within thirty years. He was the father of three great figures, Möngke, Kublai
\end{abstract}

Bu çalışmada Necmettin Erbakan Üniversitesi Sosyal Bilimler Enstitüsü Tarih Anabilim Dalında halen yürütülmekte olan Hülâg $\hat{u}^{\prime} n u n$ Hayatı ve Faaliyetleri adlı yüksek lisans tezinden elde edilen verilerden yararlanılmıştır.

** Arş. Gör., Necmettin Erbakan Üniversitesi, Sosyal ve Beşerî Bilimler Fakültesi, Tarih Bölümü, Konya/Türkiye, celikkburak1@gmail.com, Orcid: 0000-0002-8778-8931 Konya TüRKIYE 
and Hülegü, two of whom had obtained the throne of the dependent Mongolian State, the other obtained the great Khanate in Karakorum, and directly influenced the political life of the Mongols. However, Tolui's stepchildren Moge, his grandchildren Toq Temür and Kelmish Aqa, who were born from other wives and concubines, had strong influence in the domestic and foreign politics of the Mongols. Chief Khatun Sorghaghtani Beki, who was indiscriminately interested in their education, had an important role in raising all the legal and stepchildren of Tolui as qualified rulers in addition to the inheritance left to them. In this study, which is the first part of a series of articles consisting of three studies, we attempted to introduce Tolui family in integrity as well as explaining its effects on Mongolian domestic and foreign politics

\section{Keywords}

Keywords Keywords Keywords Keywords Keywords Keywords Keywords Keywords 


\section{GíRiş}

Kaynaklarda ilk kez VII. Yüzyılda "Mêng-wu" ya da "Mêng-wa" şeklinde sıradan kabileler arasında zikredilen Moğol adının, siyasi bir teşkilat ismi olarak kullanılması Cengiz Han zamanında olmuştur. (Özgüdenli, 2005, s. 225) Ataları efsanelere göre Bozkurt ve Dişi Geyik'den doğma Alan Hoa'nın en küçük oğlu Bodançar olan Cengiz, Bodançar'ın sekiz kuşak soyundan gelen Tayciut reisi meşhur Hambukay'ın torunudur. Baba soyundan Kiyat kabilesine bağlı olan Cengiz 1155 yılında Temuçin adıyla doğmuştur. (d'Ohhson, 2008, s. 37-41; Gizli Tarih, s. 1-19) Babası Yesügey Bahadır'ın düşmanları tarafından zehirlenmesi sonucunda Temuçin, büyük zorluklarla dolu bir hayat sürdükten sonra Kerayit kavminden Ong Han ile yakın dostluk kurmuş, ardından gelişen siyasi olaylar büyük oranda lehine gelişmiştir. Cengiz'in ilk büyük baskını ve başarısı, baş hatunu Börte Uçin'i, kendisini esir alan Merkitlerin elinden kurtarmasıdır. (Gizli Tarih, s. 22-49; Grousset, 1996, s. 192) Börte Uçin, Kongirat kabilesinden Dey Seçen ve eşi Çotan'ın kızıydı. O, on yaşında iken Yesügey Bahadır tarafından yolculuk sırasında Dey Seçen'in misafiriyken görülmüş ve dokuz yaşındaki Temuçin ile sözlendirilmiştir. Babasının zehirlenme vakasından yıllar sonra Temuçin, ergenlik çağlarında Dey Seçen'in kampına giderek Börte Uçin'i istemiştir. Dey Seçen, Yesügey Bahadır'ın ölmesinden dolayı ilk başta Temuçin'e kızını vermekte tereddüt etmiş ancak Börte'nin ağabeyi Alçi, babasını bu evliliğe ikna etmiştir. Böylece Temuçin ailesine dahil olan Börte Uçin, ona Cuci, Çağatay, Ögedey ve Toluy adlarında dört oğul vermiştir. Cengiz Hanlığının en meşhur şahsiyetlerinden biri sayılan Börte Uçin, sözleri ve tavsiyeleri ile kocası Temuçin'in Cengiz Han olmasını sağlayan en önemli şahsiyet tarihe geçmiştir. Börte Uçin'in Temuçin'e ilk tavsiyesi andası Camuka'yı ortadan kaldırması olmuştur. (Atwood, 2004, s. 455-456)

Cengiz Han'ın birçok kadından oğlu olmuştur. Ancak bunlardan yalnızca baş hatunu Börte Uçin'den doğan dört oğlu mühimdir. Ölümünden önce yapılan toprak taksimatı 1227'deki ölümüyle uygulamaya koyulmuştur. En büyük oğul Cuci, babasından önce öldüğü için mirası oğlu Batu'ya intikal etmiş ve Batu, Altın Orda Devletinin temelini teşkil eden Ak Ordayı kurdu. İkinci oğlu Çağatay Türkistan'da kendi adıyla anılan devletin kurucusu oldu. Üçüncü oğlu Ögedey daha önce veliaht tayin edildiğinden düzenlenen büyük bir kurultay ile Büyük Han ilan edildi. En küçük oğul Toluy'un hissesi ise İç Moğolistan ve Kırgızların yaşadığı coğrafya ve etrafındaki bölge idi. (Kafalı, 1993, s. 367-369; Ebu'l-Gazi Bahadır Han, 2009, s. 41)

\section{Toluy}

Moğolistan, İran ve Çin'de ölümünün ardından yaklaşık otuz yıl sonra teşkil olan hanedanların atası Toluy, Cengiz Han'ın ilk ve baş hatunu Börte Ucin'den doğan dördüncü ve son oğludur. Reşîüüddin ile Cüveynî gibi dönemin meşhur tarihçilerinin eserlerinde ve Muizzü'l-Ensab'da ile Çingiz-namesi ile meşhur Ebu'l-Gazi Bahadır Han'ın eserinde Tuli (Muizzü'l-Ensab, vr. 46; Ebu'l-Gazi Bahadır Han, 2009, s. 82) olarak anılan Toluy ismi, Ferdinand D. Lessing'in Moğolca-İngilizce sözlüğüne göre Toli ya da Tolı(n) biçiminde klasik Moğol lisanında kullanılmakta ve "ayna", "metal tabaka", "levha" anlamlarına gelmektedir. (Lessing, 1960, s. 321; Ebu'l-Gazi Bahadır Han, 2009, s. 82) Bu açıdan dönemin adı geçen meşhur tarihçilerinin ismi kullanma biçimleri, gerçek telaffuzun Tuli biçiminde olduğunu bizlere ispat etmektedir. Türkçe'nin çeşitli lehçelerinde de kullanılan 1-Tol, 2-Toli ve 3-Tolu kelimeleri birçok sözlükten tespit ettiğimiz üzere "Dolu", "Tam" anlamlarına gelmekte ve bunun dişında bir manaya işaret ettikleri görülmemektedir. (Abû Hayyân, 1931, s. 105; Çulha, 2006, s. 110) Bu 
açıdan Cuci ismi dışarıda tutulursa, Toluy'un diğer erkek kardeşlerinin ve babasının isimlerinin aksine onun da isminin dönemin baskın dili Türkçeden etkilenmediği, ad verilirken Moğolcaya has bir isim tercih edildiği görülmektedir. Ancak ismin yerli ve yabancı modern Moğol tarihçilerince kullanımı, tercih çokluğuna göre "Toluy", "Tuluy", "Tuli" ve "Toli" şeklinde olup araştırmacıların ekseriyeti Toluy biçimini tercih etmektedirler. (Jackson, 2017, s. 77; Atwood, 2004, s. 542; Zhao, 2008, s. 317; Yuvall, 1994, s. 19; Kafall, 2005, s. 154)

Toluy'un hakkında kaynaklar, 1206 yılındaki büyük kurultaydan sonra düzenli bir şekilde bahsetmektedir. Gençliği hakkındaki bilgilerin neredeyse yok denecek kadar az olması onun doğum tarihini ihtilaflı bir hale getirmesine rağmen birçok tarihçi 1191 yılı üzerinde birleşmektedir. (Atwood, 2004, s. 542; May, 2017, s. 189) Hakkında 1206'dan önce iki kez bahsedilen Toluy, ilkinde beş yaşında bir tatar esir tarafından neredeyse öldürülmekten kurtulmuştur. (Gizli Tarih, s. 109; May, 2017, s. 189) İkinci hadise ise 1203 yılında, yaklaşık 12 ya da 13 yaşlarında iken Sorgaktani Beki ile evlendirilme hadisesidir. (Gizli Tarih, s. 109; May, 2017, s. 189) Gizli Tarih'in aktardığı bu bilgilerin sshhatine güvenecek olursak Toluy'un, 1190-91 yıllarında, Ebu'l-Gazi ye göre ise 1192 tarihinde doğmuştur. Buna göre Toluy'un 1190-1192 yılları arasında doğduğu su götürmez gerçektir. Toluy için kaynakların hakkında verdikleri az bilgi nedeniyle gençliğinde nasıl bir eğitim aldığını bilmemekteyiz. Toluy muhtemelen annesi ve babası riyasetinde bir eğitim almıştır. Ebu'l-Gazi'nin deyimiyle Cengiz Han devri Moğol Hanlığının harbiye nazırlığı görevlerini üstlenen (Ebu'l-Gazi Bahadır Han, 2009, s. 83), askerlik mesleğinde büyük bir şöhreti olan Toluy'un, çocukluğundan beri Cengiz'in yakın maiyetindeki komutanlarla yakın ilişkiler içinde olduğu akla daha yatkın gelmektedir.

Toluy ilk olarak Ong Han'ın kardeşi Jakambo'nun küçük kızı Sorgaktani Beki ile evlendirilmiştir. (Atwood, 2004, s. 511; Reşîdüddin/Boyle, 1971, s. 159) Evlilikleri Cengiz Han'ın 1203'de Kereyitleri saf dışı bıraktığı büyük savaşın ardından gerçekleşmiştir. Onların evliliği babasının bir takdiri olarak siyasi faydalar güdülerek yapılmıştır. Cengiz Han, devleti açısından mühim bir avantaj olarak, kültürel açıdan Moğollardan daha ileride olan bu kavmi kendine tabi kılmıştır. Cengiz'in kendisi de Sorgaktani Beki'nin ablası İbaha Beki'yle evlenmiş, diğer oğlu Cuci'yi ise öteki kız kardeş Bek Tutmuş Üçin ile evlendirmiştir. (Gizli Tarih, s. 109; Polo, 2019, s. 144; Reşîü̈ddin/Boyle, 1971, s. 99) Toluy'un hanımı Sorgaktani Beki onun en kıdemli hatunu, Mengü, Kubilay, Hülâgû ve Arık Böke adlı dört oğlunun annesidir. Kerayitler, genel manada Moğol Hanlığını etkilerken özellikle Toluy Ulusunun ikbaline daha büyük oranda etki sağlamışlardır. İleri tarihlerde görüleceği üzere devlet geleneğine sahip Kerayit menşeili kadınların Toluy ve soyunun siyasi, idari ve dini birçok önemli alanında faaliyet göstermiş ve özellikle Sorgaktani Hatun, Toluy soyunun iktidara gelmesinde en önemli amiller arasında öne çımıştır. Sorgaktani, Toluy'un ölümünün ardından ailenin başına geçmiş, Toluy Ulusunun iktidara çıkma sürecinde etkin bir rol oynayarak o günün dünyasında çok tanınan bir kadın figür haline gelmiştir. (Manz, 2011, s. 130; Abû'l-Farâc, 1987, s. 531)

Toluy, siyasi olsun ya da olmasın kendi döneminde olaylara yön veren, değiştiren etkili bir şahsiyet olmuştur. Cengiz'in tüm Moğolistan'ı birleştirdiği savaşlarda adı geçmemektedir. Onlu yaşlardan itibaren savaşlarda bulunduğunu tahmin edersek Kerayitlerin mağlup edildiği savaş ve sonrakilere katılmış olmalıdır. Kaynaklara yansıyan ilk muharebesi 1211 tarihli Kin seferinde vuku bulmuştur. Yaklaşık olarak yirmili yaşlarında katıldığı bu seferde, eniştesi Çigü ile yürüttügü başarılı operasyonlar ile kendini kanıtlayan Toluy, Cengiz Han tarafından büyük bir taltife ve ödüllendirilmeye muhatap edilmiştir. Ağabeylerinden daha üstün askeri becerilere sahip olduğunu 1211 tarihli Kin seferinde kantlayan Toluy 1219 Harizm seferi ve Ögedey ile çıtığ 
sırasında beraber çıktığı Kin seferinden dönüşte, Tula ve Onon ırmaklarının ayrımı olan yere hasıl olunduğu sıralarda amansız bir hastalığa yakalanarak Ekim 1232'de vefat etmiştir. (d'Ohhson, 2008, s. 171-172; Atwood, 2004, s. 542; May, 2017, s. 189; Ebu'l-Gazi Bahadır Han, 2009, s. 117-118) Toluy öldükten sonra bütün Moğol imparatorluğundaki ünü ve şöhreti daha da büyüyerek devam etmiştir. Nitekim Moğol lisanında "ayna" anlamına gelmekte olan Toluy adı, ölümünden sonra Moğol gelenek ve göreneğine göre yasaklanmış ve bu kelime bir tabu haline gelmiştir. Moğollar, Toluy öldükten sonra bu kelimeyi hayatlarından çıkarmış Türkçe ayna manasına gelen Gözüg kelimesini kullanmaya başlamışlardır. Toluy'un, çeşitli kaynaklardan tespit edebildiğimiz kadarıyla baş hatunu Sorgaktani Beki ile birlikte Dokuz, Lingkun, Saruk, Bumur ve Bayan adlı altı hatunu, on erkek ve üç kız çocuğu dünyaya gelmiştir. Oğulları sırasıyla: 1-Mengü Han(resmi), 2-Cörike(üvey ), 3-Kutuktu(üvey), 4-Kubilay Han(resmi), 5-Hülâgû Han(resmi), 6-Arık Böke(resmi), 7-Böçek(üvey), 8-Möge(üvey), 9-Sögetey(üvey), 10-Sübedey (üvey)'dir. Kızları: 1-El Temür(Yantemür), 2-Yesübuha, 3-Tümügen(Dumugan)'dir.

\section{Eşleri}

\subsection{Sorgaktani Hatun}

Sorgaktani Beki, Kerayitlerden Jakambo'nun kızı ve Temuçin'in önce müttefiki ardından düşmanı olan Kerayit Hanı Ong Han'ın yeğenidir. (Durak, 2008, s. 251-253; Akkuş, 2020, s. 118). Sorgaktani Hatun'un gençliği hakkında çok fazla bilgi yoktur. Hakkında ilk bilinen husus, Cengiz Han'ın İç Moğolistan'da güçlendiği XIII. Yüzyıl başında, onun en küçük oğlu Toluy ile evlendirilme hadisesidir. Siyaseten gerçekleştirilen bu evlilik Cengiz Han'ın Kerayitleri bozguna uğrattığ1 yıllarda meydana gelmiştir. Bundan daha önceki yıllarda, 1200 başlarında henüz Kerayit seferi öncesi Cengiz Han, Ong Han'dan kızlarını ve yeğenlerini kendi oğulları ile evlendirmek istemiş ancak reddedilmiştir. 1203'te Cengiz, Ong Han'ı ortadan kaldırdıktan sonra bu amacına kavuşarak Jakambo'nun kızı Sorgaktani Beki'yi Toluy ile evlendirmiş, kendisi de ablası İbaha Beki'yi almıştır. (Durak, 2008, s. 252-253) Mengü, Kubilay, Hülâgû ve Arık Böke'nin annesi olan Sorgaktani Beki, Toluy'un baş hatunudur. (Muizzü'l-Ensab, vr. 46; Khamidova, 2017, s. 861)

Kocasının 1232'de Güney Çin seferinde ölümü sonrası Sorgaktani Beki, Ögedey Han'dan büyük ihtimam görmüştür. Zira Toluy, Moğollar arasında askeri şöhreti ile ünlenmiş, ağabeyi Ögedey Han'a canını kurban ederek onun kurtulmasına vesile olmuştur. Bu hatıra halk arasında bilinmesine ve konuşulmasına rağmen sık sık Sorgaktani Beki tarafından Ögedey Hanı şahsına da hatırlatılmaktaydı. (Reşîdüddin/Boyle, 1971, s. 39; Cahun, 2006, s. 214-216) Cüveynî, Ögedey Han'ın onun her talebini hemen yerine getirdiğini aktarmaktadır. (Cüveynî, 2013, s. 454)

Sorgoktani Beki, 1232'den itibaren yaşamını çocuklarına adayarak iç mücadeleden uzak durmuş, ince zekâsı ile Moğollar arasındaki en etkili kadın şahsiyetlerden biri haline gelmiştir. Reşîdüddin, Sorgaktani Beki'yi büyük bir saygıyla anmakta, Cengiz Han'ın anasıyla bir tutmakta ve hatta bazı noktalarda Sorgaktani'nin Cengiz'in anasından daha üstün bir konumda olduğunu ifade etmektedir. (Reşîdüddin/Boyle, 1971, s. 168-169) Başlarda Ögedey Ulusunun itimadını ve büyük saygısını kazanan Sorgaktani Beki, 1251'e kadar diğer aileler ve özellikle Cuci Ulusu ile başlarda önemsiz fakat zamanla büyüyerek güçlenen bir müttefiklik ilişkisi kurmuştur. (Reşîdüddin/Boyle, 1971, s. 168-169) Bizce Hatun'un başarılı siyaseti Toluy Ulusunun Moğol Hanlığının tümünde hâkim olmasında birinci dereceden sebepler arasında yer almaktadır. Zira Toluy'un ölümünden Mengü'nün iktidar oluşuna dek hatun siyasi hırslara kapılmamış, iç çekişmelerden uzak durarak yalnızca evlatlarının ikbalini amaçlamıştır. Zaten Mengü'nün iktidarından birkaç sene sonra vefat etmiştir. (Durak, 2008, s. 257.) Öldükten birkaç yıl sonra 
Toluy Ulusu Çin , Moğolistan ve İran'da iktidarı ele alarak, Moğol imparatorluğunun büyük bir kısmına hâkim olmuşlardır.

Toluy ailesinin en önemli şahsiyetlerinden biri olan Sorgaktani Hatun tutucu bir Nestûrî Hıristiyandır. Onun Hıristiyan olması nedeniyle bu din Toluy Ulusu için ehemmiyetli bir dindi. Ancak Cüveynî ve Reşîdüddin gibi yazarlar eserlerinde bize hatunun diğer dinlere ve bilhassa Müslümanlık dinine samimi yaklaştığını diğer dinlere ise zulmetmekten kaçındığını aktarmaktadır. O, Seyfeddin el-Bâherzi'ye büyük miktarda para vererek zamanında Moğollardan büyük zarar gören Buhara' da Müslümanların eğitimi için bir Medrese yaptırmıştır. Yine Buhara'nın civar köylerini satın alarak Medrese hocaları ve öğrencilerinin geçimine vakfetmiş, çoğu zaman Müslüman fakir ve düşkünlere yardım etmiştir. (Cüveynî, 2013, s. 455; Reşîdüddin/Boyle, 1971, s. 168-169; Spuler, 1957, s. 202)

\subsection{Dokuz Hatun}

Hülâgû'nun baş hatunu olan Dokuz Hatun, Kerayitlerden Ong Han'ın torunudur. O Sorgaktani Beki ile beraber Toluy'a verilmiş ancak bu evlilik tam olarak gerçekleşmemiştir. Zira onun hiç çocuğu olmayınca ve Toluy erken yaşta ölünce Hülâgû Moğol âdetleri gereğince üvey annesi Dokuz'u hanımı olarak almıştır. Dokuz Hatun Hülâgû'nun ilk eşi olmamasına rağmen İlhanlılar Devleti içinde önemli bir kadın figürdür. Nitekim onun bu önemi babası Toluy ile evlilik geçirmiş olmasından kaynaklanır. Bu nedenle hatun saygınlık açısından Hülâgu'nun diğer hatunlarından daha üstündür. Hülâgû, Dokuz Hatun'la İran seferinin başlarında henüz Amuderya'yı yeni geçmişken evlenmiştir. Nestûrî bir Hıristiyan olması bakımından Dokuz Hatun, İran ve çevre bölgelerde Hıristiyanları birçok konuda İlhanlılar Devleti tarafından ayrıcalıklı ve öncelikli bir zümre haline getirmiştir. Hülâgû birçok bölgede bu hatunun vâsıtasıyla kiliseler kurdurmuştur. Hatun Hıristiyanlık dininde o derece tutucuydu ki sarayının önünde dahi daima kilise bulundurmuş, ibadethanenin çanları sürekli çalmıştır. Dokuz Hatun, Hülâgû'nun ölümünün müteakip bir yıl içinde vefat etmiştir. (Reşîdüddin/İlhanlılar, 2013, s. 4; Yuvalı, 1994, s. 50; Khamidova, 2017, s. 361; Atwood, 2004, s. 541-542; Taşağ11, 2001, s. 415-416)

\subsection{Lingkun Hatun}

Muizzü'l-Ensab ve Reşîüuddin'in Şu'b-1 Pencgâne adlı eserinde Toluy'un önemli hatunları içerisinde zikredilen Lingkun Hatun, son Nayman Hanı ve daha sonra Karahıtay tahtını ele geçiren Küçlük Han'ın kızıdır. (Khamidova, 2017, s. 861; Zhao, 2008, s. 133; Muizzü'1-Ensab, vr. 46) Lingkun Hatun'un Toluy ile evliliği 1205 yılı civarında gerçekleşmiş olmalıdır. Nitekim Cengiz bu tarihte Naymanların üzerine giderek onları yenmiş ve topraklarını ülkesine katmıştır. Savaş sonrası Küçlük Han, ülkeden yanında az bir askeri kuvvetle kaçarken savaş alanında bulunan babası Tayang esir olarak ele geçirilmiştir. (Delibalta, 2019, s. 38-40) Büyük olasılıkla Küçlük Han ülkeden kaçarken ailesini yanına alamamış, babası Tayang ile beraber onlarda Moğollar'ın eline geçmiştir. Naymanlarla yaptığı muharebe sonrası Cengiz, Kerayit örneğinde olduğu gibi Lingkun'u Toluy ile evlendirmiş, Nayman hanedanı ile akrabalık müessesesi tesis ederek bu kavmin muhabbetini ve yakınlığını kazanmak, üzerlerinde Moğol nüfuzu oluşturmak istemiştir. Reşîüuddin Câmiu't-Tevârîh adlı eserinde Toluy'un Lingkun Hatun'dan bir oğlan ve bir kız evladı olduğunu zikretmekte oğlunun isminin Kutuktu, kızının ismini ise El Temür olarak belirtmektedir. (Reşîüüdin/Boyle, 1971, s. 312)

Kutuktu, Toluy'un bütün oğulları arasında ikinci oğlu olduğundan Mengü ile Kubilay'ın ortasında, 1209-1215 yılları arası doğmuş olmalıdır. Bu nedenle Karahıtayların yıkıldığı ve Küçlük Han'ın öldürüldüğü 1218 tarihinden (Delibalta, 2019, s. 49-51) sonra evlendirilmeleri imkansızdır. Bu nedenle ilk verilen tarih yani 1205 yılı daha dikkate değer bir tarihtir. Hatun 
Nayman hanedanına mensup olduğundan dolayı büyük olasılıkla Nestûrî bir Hıristiyandır. Reşîdüddin eseri Câmiu't-Tevârîh'te zeki ve yetenekli bir kadın olarak ifade ettiği Lingkun hatunun ordosunun, ölümünü müteakip Büyük Han'ın emriyle Arık Böke'nin oğlu Melik Timur'un idaresine tahsis edildiğini zikretmektedir. (Reşîdüddin/Boyle, 1971, s. 312) Lingkun Hatun bu kayıttan anlaşıldığına göre 1259'dan önceki bir tarihte ölmüştür. Zira 1260'ta Büyük Han olan Kubilay'ın Lingkun Hatun'un sarayını en büyük muhaliflerinden Arık Böke'nin oğluna tahsis etmesi zor bir ihtimal olarak görünmektedir. Bu nedenle Lingkun'un ordosu Mengü Han ya da önceki iktidarlar zamanında Melik Timur'a intikal ettirilmiş olmalıdır. Öyle ise sarayın Arık Böke oğlu Melik Timur'un idaresine geçmesi esas mirasçı olan Kutuktu'nun annesinden önce öldüğünü göstermektedir.

\subsection{Saruk Hatun}

Reşîdüddin'in Câmiu't-Tevârîh adlı eserinde hakkında kısmen bahsettiği Nayman kökenli Saruk Hatun, Toluy'un genç yaşta ölen ikinci oğlu Cörike'nin (Reşîdüddin/Boyle, 1971, s. 160) ve sekizinci oğlu Möge'nin (Reşîdüddin/Boyle, 1971, s. 241) annesidir. Ailesi hakkında bilgiye ulaşamadığımız Saruk Hatun'un Muizzü'l-Ensab'ta yalnızca ismi zikredilmiş hakkında başka bilgi verilmemiştir. (Muizzü'l-Ensab, vr. 46) Nayman kavminden geldiği bilgisi dikkate alındığında Saruk Hatun muhtemelen Lingkun Hatun ile akrabadır ve onunla aynı yıllarda Toluy ile evlendirilmiştir. Nitekim Toluy'un oğlu Cörike'nin ardından Lingkun Hatun isimli eşinden doğan oğlu Kutuktu dünyaya gelmiştir. Nayman kavminden ve yüksek olasılıkla Küçlük Han'ın sarayından olduğunu tahmin ettiğimiz Saruk Hatun, bu yüzden büyük olasılıkla Nestûrî bir Hıristiyan'dır. Saruk Hatun, Reşîdüddin'in eserinde verdiği bilgiye göre Kubilay doğduğunda onun sütanneliğini üstlenmiştir. (Reşîdüddin/Boyle, 1971, s. 312)

\subsection{Bumur Hatun}

Bumur Hatun, Reşîdüddin'in Şu'b-1 Pencgâne adlı eserine göre Toluy'un önemli hatunlarından olup Kerayit kabilesinden Ong Han'ın oğlu Angu'nun kızıdır. (Khamidova, 2017, s. 861) Bumur Hatun'un hakkında Çin kaynakları ve Muizzü'l-Ensab sessiz kalmakta ismi dahi geçmemektedir. Bu husus Bumur hatunun erken tarihlerde öldüğünü ya da Toluy ailesinde etkili bir şahsiyet olmadığını gösteriyor olabilir. Bumur Hatun, dönemin kaynaklarına yansımasa bile Sorgaktani Beki ile aynı yıl, Cengiz Han'ın Kerayitlere hâkim olduğu dönemde Toluy'yle evlendirilmiş olmalıdır. Kerayit hanedan ailesine mensup olmasından dolayı Bumur Hatun muhtemelen tıpkı yakın akrabası Sorgaktani gibi Nestûrî Hıristiyandır. Nesebi ve dini tutumu açısından düşünüldüğünde, yine diğer hanedan üyesi Kerayitli hatunlar gibi sağlam bir devlet geleneğini kültürüne sahip olduğu ve iyi bir eğitimden geçtiği açıtır. Tuluy'un Bumur Hatun'dan herhangi bir oğlu ya da kızı olmamıştır.

\subsection{Nayan Hatun}

Toluy'un eşlerinden Nayan Hatun'un, Reşîdüddin'in Şu'b-ı Pencgâne adlı eserinde yalnızca ismi zikredilmiştir. (Muizzü'l-Ensab, vr. 46) Onun hakkında Muizzü'l-Ensab isminden ve Kongirat kavmine mensup olduğundan bahsetmiştir. (Khamidova, 2017, s. 861) Adı geçen kaynaklarda açıç̧a belirtilmese de Nayan Hatun muhtemelen, Toluy'un dayısı Kongirat kabilesinden Alçi Noyan ailesindendir. (Zhao, 2008, s. 211) Moğollar tarafından "İmparatorluğun Dayısı" unvanını alan Alçi Noyan, Börte Uçin'in ağabeyidir. Nayan Hatun'un akrabaları ya da kardeşlerinden Çigü, Cengiz Han'ın kızı Temülün ile evli iken Çabi Hatun, Yüan hanedanının kurucusu Kubilay Han ile evliydi. (Atwood, 2004, s. 456) Akrabalıkları, dolayısıyla münasebetleri açısından Toluy ailesinin önemli ve etkili şahsiyetlerden biri olduğunu düşündüğümüz Nayan 
Hatun'un Toluy'dan hiç çocuğu olmamıştır. Reşîdüddin eseri Câmiu't-Tevârîh'te Nayan Hatun'un Sorgaktani Beki tarafından Arık Böke ile evlendirildiği, o öldüğünde Arık Böke'nin diğer eşleri gibi kendi sarayına geri döndüğünü söylemektedir. (Reşîdüddin/Boyle, 1971, s. 311312) Nayan Hatun eğer Arık Böke'nin diğer oğullarından biriyle evlendirilmediyse büyük olasılıkla Kubilay'ın sarayına yani Çin'e dönmüş olmalıdır. Nitekim Toluy ailesinin iktidara geldiği ve Nayan Hatun'un evlilik için çıktığı yer Karakorum o esnada Hanbalık'a taşınmış durumdadır. Hatunun Toluy'dan ve Arık Böke'den tespit edilebilmiş oğlu ya da kızı olmamıştır. Muhtemelen hatun eğer Reşîdüddin'in zikrettiği gibi yurduna döndüyse, geldiği Çin'de, Yüan hanedanının ileri gelenlerinden biri ile evlendirilmiş olmalıdır.

\section{Oğulları ve Kızları}

\subsection{Oğulları}

\subsubsection{Mengü}

Baş hatun Sorgaktani Beki'den doğan Mengü, Toluy'un ilk oğlu olarak 10 Ocak 1209'da doğmuştur. (Reşîdüddin/Boyle, 1971, s. 197; Atwood, 2004, s. 362) Mengü Han, 1251 kurultayı ile tahta çıkarak Moğol tahtına çıkan dördüncü Büyük Han olmuştur. Moğol tahtında sekiz yıl iktidarda kalan Mengü Han, selefleri Töregene Hatun (Naiblik), Güyük ve Oğul Gaymış (Naiblik) zamanında yaşanan iç karışıklıkların yıprattığı bir devletin başına geçmiştir. (Yuvalı, 2004, s. 4041) Mengü Han, duraklamaya giren Moğol Hanlığını tekrar eski güçlü günlerine döndürmüş, doğu ve batı yönünde yeni genişleme hareketleri başlatmıştır. İktidara geldiğindeki ilk işi, yaşanan iç mücadeleler sonucu uzak bölgeler ile başkent Karakorum'un zayıflayan bağını kuvvetlendirmek olmuştur. Bu nedenle o, Cengiz ve Ögedey hanlar devrindeki Merkeziyetçilik politikasını canlandırmayı amaçlamıştır. Merkezileştirme politikasının ilk adımı olarak kardeşlerinden Hülâgû'yu İran'a, Kubilay'ı Çin'e göndererek buralarda merkeze bağlı şube Moğol devletleri tesis ettirmiş adı geçen bölgelerde Moğol nüfuzunu başkent Karakorum ve Toluy Ulusu lehine güçlendirmiştir. (Cüveynî, 2013, s. 426; Yuvalı, 1994, s. 52-53; Reşîuüddin/İlhanlılar, 2013, s. 13) Merkeziyetçilik politikası bağlamında yaptığı diğer düzenlemeler ise halefleri zamanında merkez hazinesine borcu olan şahısların bütün borçlarını kapattırması; Argun Aka'ya yaptırdığı nüfus sayımı ile devletin hazinesine girecek yeni vergi ve gelir kalemleri tespit ettirmesi; Cengiz Han'dan sonra verilmiş bütün payza ve yarlıkları toplattırması sayılabilir. (Yuvalı, 1994, s. 41-42; Atwood, 2004, s. 363-364) Tüm bunlarla beraber Mengü Han, Yeluçutsay'ın Moğollara kabul ettirdiği ve uzun zamandır kullanılagelen "hane başı" vergisini kaldırtarak Mahmud Yalavaç'ın "kişi başı" vergi almayı esas alan "Dink" sistemiyle değiştirmiş, batı bölgesine Argun Aka gibi çok mühim bir ekonomisti atayarak buralarda eksik toplanan vergi işlerini disipline etmiştir. Mengü 1258'de Songlar üzerine askeri bir sefer gerçekleştirmiş, başarıyla yürütülen bu seferin henüz ortasında, 11 Ağustos 1259 tarihinde ölmüştür. (Reşîdüddin/Boyle, 1971, s. 194-237; Rossabi, 2015, s. 41-44)

\subsubsection{Cörike}

Muizzü'l-Ensab'a ve Reşîüddin'e göre Saruk adlı hatundan doğan Cörike, Toluy'un Mengü'den sonra doğan ikinci oğludur. (Reşîdüddin/Boyle, 1971, s. 160; Muizzü'1-Ensab, vr. 48) Kubilay'ın ve Mengü'nün doğum tarihleri göz önüne alındığında 1209-1215 yılları arasında doğmuş olmalıdır. Hakkında pek bilgi bulunmayan Cörike, Qinghi Zhao'nun Yüanşi Tarihi'nden aktardığına göre Börte Uçin'in ağabeyi Alçi Noyan'ın kızı Bulga Hatun ile evlenmiş ancak bu evliliklerinden hiçbir çocukları olmamıştır. (Zhao, 2008, s. 118) Aynı zamanda teyzesi olan Bulga Hatun'la evlilikleri 1238 yılında, Ögedey Han'ın iktidarı sırasında meydana gelmiştir. Zira onun Bulga Hatun ile evliliği, kız kardeşi Yesübuha ile Alçi Noyan oğlu Voçen'in 1238 yılındaki 
evliliklerine bir karşılık olarak gerçekleştirilmiştir. (Zhao, 2008, s. 103) Öyleyse Ögedey devrinde yaşadığını anladığımız Cörike en azından yirmi üç yaşını görmüştür. Ne zaman öldüğü ile alakalı herhangi bir bilgi bulunmamaktadır.

\subsubsection{Kutuktu}

Lingkun Hatun'dan doğan Kutuktu, Toluy'un Cörike'den sonra doğan üçüncü oğludur. (Reşîdüddin/Boyle, 1971, s. 160; Khamidova, 2017, s. 861; Muizzü'l-Ensab, vr. 48) Annesi Lingkun tarafından aynı zamanda Küçlük Han'ın da torunu olan Kutuktu'nun kısa bir ömrü olmuştur. Kutuktu, Buta Ekeçi adında Kıpçak kökenli bir cariye ile evlenmiş, bu hatundan Tükel Buka isminde bir oğlu olmuş ancak Tükel Buka henüz ergenlik yaşlarında iken vefat etmiştir. (Reşîdüddin/Boyle, 1971, s. 312) Kutuktu'nun Buta Ekeçi Hatun'dan ayrıca iki kızı daha olmuştur. Bunlardan büyük kızının ismi Kelmiş Aka'dır. Kutuktu, kızı Kelmiş Aka'yı Ongirat kabilesinden Salciday Küregen ile evlendirmiştir. Reşîüuddin, aynı zamanda Tokta'nın kayınpederi olan Salciday'ın, Cuci Ulusu içerisindeki en önemli emirlerden olduğunu zikretmekte ve 1301-1302'de öldüğünü ifade etmektedir. Yazar devamında Salciday'ın ölümünün ardından Kelmiş Aka'nın hala hayatta olduğunu, Altın Orda hanı Tokta ve diğer Cuci prensleri tarafından büyük bir ihtimam gösterildiğini ifade etmektedir. Öyle ki Kelmiş Aka'nın anneannesi Olcay Hatun, aynı zamanda Tokta Han'ın da annesi idi. Reşîdüddin devamında Kelmiş Aka'nın o dönemde Gazan Han ile yakın bir muhabbet içinde olduğu ve Deşt-i Kıpçak'ta yaşanan gelişmeler ile ilgili sürekli onu bilgilendirdiğini de zikretmiştir. (Reşîüüddin/Boyle, 1971, s. 160) Kelmiş Aka'nın bu çabası Toluy Ulusu ile Cuci Ulusu arasındaki dostluğu güçlendirerek aralarındaki eski düşmanlıkları durdurmuştur. Hatun yalnızca İran'daki Toluylular ile değil Çin'dekiler ile de dostluk münasebetleri içindedir. Bunu Kubilay Han'ın oğulları Nomoghan ve Kökücü'nün ele geçirilip Mengü Temür'a teslim edilmeleri hadisesinden anlamaktayız. Zira iki prens aralarının bozuk olduğu kuzenleri Sögötü oğlu Tok Temür ve diğer kuzenleri Mengü oğulları tarafından esir edilmişlerdir. Olaydan sonra Kelmiş Aka, Kubilay oğullarının güvenliği ve kurtarılması amacıyla esirlik hayatları boyunca büyük çaba sarf etmiş, neticede kısa vadede olmasa da uzun vadede onları koruyabilmiş, Çin'e geri gönderilmelerini sağlamıştır. (Rossabi, 2015, s. 106) Kelmiş Aka'nın hanesi ayrıca Cuci Ulusunun iç siyasetinde önemli bir etkiye sahiptir. Zira kocası Salciday Küregen, Tokta ve Nogay arasında çıkan çatışmalarda hanedan ailesinin tarafında yer alarak Nogay'a karşı muazzam bir mücadele vermiş, ordunun meşhur sağ kol komutanı Nogay'ın öldürülmesinde ve oğullarının Deşt-i Kıpçak'ta ki nüfuzlarının azaltılmasında mühim bir rol oynamıştır. (Reşîdüddin/Boyle, 1971, s. 124-126; Hope, 2016, s. 47) Kutuktu'nun ikinci kızı ise Şirin Aka'dır. Üshin kabilesinden Tukçi Küregen ile evlenen Şirin'in hayatı ve politik faaliyetleri hakkında henüz bilgi bulunamamaktadır. (Reşîdüddin/Boyle, 1971, s. 312; Khamidova, 2017, s. 861; Muizzü'1-Ensab, vr. 48) Kutuktu, Lingkun Hatun başlığı altında açılanırken söylendiği gibi muhtemelen 1259 'dan önceki bir tarihte ölmüştür.

\subsubsection{Kubilay Han}

Baş hatun Sorgaktani Beki'den doğan Kubilay, Toluy'un dördüncü oğlu olarak 1215'de doğmuştur. (Atwood, 2004, s. 457; Khamidova, 2017, s. 861; Muizzü'l-Ensab, vr. 48) Cengiz Han'ın en sevdiği torunu olan Kubilay'ın çocukluğunda çok ciddi bir eğitimden geçmiş olduğunu anlamaktayız. Mengü Han zamanı iktidarın genişleme siyasetinden ötürü kardeşi Hülâgû İran'ın zaptıyla görevlendirilirken Kubilay, Çin'de hâkimiyet sağlamakla görevlendirilmiştir. Kısa süre içinde Güney Çin'i ele geçirmiş, Moğol idari ve ekonomik müesseseleri dahilinde büyük reform hareketleri başlatmıştır. (Özgüdenli-Prazniak, 2016, s. 8889) 1260 'da Mengü Han'ın ölümü üzerine kendisine karşı uzun süre devam etmiş olan iktidar 
mücadeleleri ile uğraşmak zorunda kalmıştır. Bunun ilk safhası Arık Böke ile beraber aynı zamanda kendini Büyük Han ilan etmesiyle başlamıştır. Arık Böke ile girdiği mücadeleyi onu mağlup ederek Kubilay, Büyük Han unvanını kazanarak tarihte Çin'e hükmetmiş ilk yabancı hükümdar unvanını almıştır. (Rossabi, 2015, s. 58-60) Kubilay'ın en radikal icraatı Moğol başkentini Karakorum'dan Hanbalık'a taşımak olmuştur. 1268 yılında tekrar iç mücadeleler ile uğraşmak zorunda kalan Kubilay, bu sefer kendine başkaldıran Ögedey'in torunu Kaydu ile savaşmış ve onu bozguna uğratarak ortadan kaldırmıştır. (Rossabi, 2015, 103-111) 1276'da uzun yıllar mücadele edilen Song hanedanını yıktığında Çin'in tek hâkimi sıfatını kazanmıştır. Kubilay böylece Çin tarihindeki yirminci resmi hanedan olan Yüan hanedanını kurmuştur. Büyük Okyanustan Akdeniz'e ve Doğu Avrupa'ya ulaşan toprakların hepsinde tek hâkim sıfatını kazanan Kubilay Han 18 Ekim 1294'te ölmüştür. Evliliklerinden kırk yedi oğlu ve çok sayıda kızı olmuştur. Reşîdüddin onun birçok eşi ve cariyesi olduğunu ifade etmiştir. Ancak onun baş eşi Kongiratlardan Alçi Noyan'ın kızı Çabi Hatun'dur. Bu hatun Maymun yılında (1283-1284) vefat etmiştir. Kubilay'ın bu hatundan toplamda on iki oğlu olmuştur. (Reşîdüddin/Boyle, 1971, s. 241300; Atwood, 2004, s. 457-460).

\subsubsection{Hülâgû Han}

Baş hatun Sorgaktani Beki'den doğan Hülâgû, Toluy'un beşinci oğlu olarak 1217'de doğmuştur. (Atwood, 2004, s. 225; Khamidova, 2017, s. 861; Muizzü'l-Ensab, vr. 48) Hülâgû'nun çocukluk ve gençlik yıllarında bir av başarısı nedeniyle dedesi Cengiz Han tarafından mükafatlandırıldığı kaydı dışında erken tarihlerde kendisi hakkında başka bir bilgimiz yoktur. (Yuvalı, 1998, s. 473) Mengü Han'ın merkeziyetçi politikası sebebiyle İran'ın ve daha ilerisinin zapt edilip bölgede Moğol nüfuzunun yerleştirilmesi göreviyle batı bölgelerine gönderilmiştir. (Cüveynî, 2013, s. 497) Bu bölgeler Cengiz Han döneminde Moğollar'a bağlanmış, Ögedey sonrası yaşanan iç mücadeleler sırasında merkezle bağları zayıflamıştır. 1251'de başkentte yapılan kurultaydan çıkan karara göre Kubilay Çin'in zaptına atanırken Hülâgû'de İran'ın ele geçirilmesi görevini almıştır. Mengü Han Hülâgû'ya görevinde başarılı olması için ordunun onda ikisi verilmesini ve hanedan prenslerinden aile başı bir kişinin ona katılmasını zorunlu tutmuştur. (Reşîdüddin/Boyle, 1971， s. 104-122) 24 Ağustos 1252'de başkentten ayrilan Hülâgû'nun öncüsü Ketboğa Noyan batıya yöneldiğinde İran seferi başlamıştır. (Yuvalı, 1994, s. 60) Hülâgû, kurultaydan çıkan kararlar ve Mengü'nün tavsiyelerinden kıl kadar sapmayarak 1256 'da İsmailileri ortadan kaldırmış, 1258'de ise Bağdat'ı ele geçirerek Abbasi Halifeliğini yıkmıştır. (Yuvalı, 1998, s. 473-474) Hülagü kurultaydan aldığı bu iki önemli görevi hallettikten sonra 1259 yılında İlhanlı başkenti Tebriz'den kalkarak Suriye ve Mısır yönünde ilerlemeye başlamıştır. Ancak sefer esnasında ağabeyi Mengü Han'ın ölmesi nedeniyle aniden orduyu Ketboğa Noyan'a teslim ederek süratle Karakorum'a dönmüştür. Bölgede Kubilay ve Arık Böke arasında ortaya çıkan mücadele de Kubilay Han tarafında bulunan Hülâgû bu işlerle uğraşırken Suriye' de bulunan ordusu ağır bir darbe yemiştir. Zira onun emriyle seferi devam ettiren Ketboğa Noyan, 3 Eylül 1260'ta Aynicâlût mevkiinde Seyfeddin Kutuz emrindeki Memlük ordusuyla karşılaşmış, mağlup edilerek öldürülmüştür. (Özaydın, 1991, s. 275-276) Aynicâlût'ta Moğolların hezimete uğraması Hülâgû'nun batıda yaptığı genişleme operasyonuna büyük bir duraklama getirmiş hatta o andan itibaren elinde bulunan yerleri dahi zorlukla koruyabilmiştir. Hülâgû ağabeyinin cenazesinden döndükten sonra Altınordu Devletine karşı Azerbaycan havalisinin hâkimiyeti için yoğun bir mücadeleye girişecektir. Hayatının son yıllarını Berke Han ile mücadele içinde geçen Hülâgû, 8 Şubat 1265 'te ölmüştür. Hülâgû'nun on iki karısından on dört oğlu ve yedi kızı olmuştur. (Reşîdüddin/Boyle, 1971, s. 161; Reşîdüddin/İlhanlılar, 2013, s. 56-57; Yuvalı, 1998, s. 475) 1256 'da İsmailileri ortadan kaldırarak İran'da kurduğu İlhanlılar Devleti, 
Hülâgû'dan Gazan Han'a kadar geçen süre zarfınca daima merkezdeki Büyük Han'a bağlı kalmıştır. Gazan Han ile birlikte merkezdeki Büyük Han'ın İlhanlılar üzerindeki nüfuzu azalmış, basılan paralarda artık Büyük Han'ın adına rastlanılmadığı görülmüştür. (Yuvalı, 1994, s. 160161)

\subsubsection{Arık Böke}

Toluy'un Sorgaktani Beki'den doğan en küçük oğlu ve tüm oğulları arasında altıncısıdır. Arık Böke çocukluğu ve gençliğinden itibaren bozkır kültürüyle yakın bir bağ içinde büyümüştür. Nitekim gençliğinden beri Çin kültürüyle samimi bir bağ kuran ağabeyi Kubilay 1248'de kardeşi Arık Böke için annesi Sorgaktani Beki'ye Konfüçyüsçü öğretmenler önermiş ancak Arık Böke'nin Kubilay'ın aksine Çin okuluna uzak duruşu nedeniyle kabul edilmemiştir. Annesi Sorgaktani Beki'nin ölümünden sonra onun ordosu en küçük oğul olması nedeniyle Arık Böke'ye intikal etmiştir. Mengü Han'ın 1259'da seferdeyken ölmesi üzerine Karakorum'da kurultay toplayarak kendini han ilan ettiren Arık Böke, ağabeyi Kubilay'da aynı şekilde davranınca ağabeyiyle iktidar mücadelesine girimiştir. İktidar mücadelesinden ölümüne dek politik yaşamının çoğu Kubilay Han'la çekişerek geçmiştir. 1264' de yargılanarak hapsedilen Arık Böke 1266'da ölmüştür. Onun oğulları sırasıyla Yobugur, Melik-Timur, Kutuga, Tamaçi ve Nayrahu Buga'dır. (Reşîdüddin/Boyle, 1971, s. 161; Atwood, 2004, s. 21-22)

\subsubsection{Böçek}

Hangi hatundan doğduğu bilinmeyen Böçek, Toluy'un yedinci oğludur. (Khamidova, 2017, s. 861; Muizzü'l-Ensab, vr. 46) Plano Carpini'nin zikrettiği Budçak adlı kişiyle muhtemelen aynı kişidir. Ögedey Han'ın İkinci Kurultay'da çıkardığı Deşt-i Kıpçak seferine kardeşi Mengü ile beraber Batu'nun emrinde katılmıştır. (Cüveynî, 2013, s. 246) Böçek ve Mengü 1235'te, Deşt-i Kıpçak bölgesinde Moğol ordusuna karşı şiddetli bir gerilla hareketi yürüten Kıpçak kökenli komutan Bacman'ı (Atwood, 2004, s. 455) ortadan kaldırmışlardır. Hatta meşhur tarihçiler Reşîdüddin ve Cüveynî, Bacman'ı bizzat kendi eliyle öldürenin Toluy oğlu Böçek olduğunu rivayet etmektedirler. (Cüveynî, 2013, s. 456-457; Reşîüüddin/Boyle, 1971, s. 56-59) Reşîdüddin Câmiu't-Tevârîh adlı eserinde Böçek'in birçok eşi ve çocuğu olduğunu zikrederek en önemli oğlunun Sebilger olduğunu söyler. Yazar devamında mübalağalı bir şekilde Sebilger'in yüz oğlu olduğunu ve hepsinin Temür Han'ın sarayında bulunduklarını ve hepsinin adlarını bilmediğini zikreder. (Reşîdüddin/Boyle, 1971, s. 161) Reşidüddin, Camîu't-Tevarih adlı eserinde bilgi sahibi olduğu Sebilger soyunu şu şekilde açılar:

1-Sayın Buka: Sayın Buka'nın oğulları: 1-Daşman, 2-i̇lahudar.

2-Jahutu: Jahutu'nun oğulları: 1-Töre Timur.

3-Tekşi: Tekşi'nin çocuklarının isimleri bilinmemektedir.

4-Tübşin: Tübşin'nin oğulları: 1-Bülteçer, 2-Süt (Sarat), 3-Bektey, 4-Boralçi. (Reşîdüddin/Boyle, 1971, s. 162)

Muizzü'l-Ensab ise Möge'nin Sebilger ve Amkiratay adlı iki oğlu olduğunu zikreder ve şecerelerini şu şekilde açıklar:

1-Sebilger oğlu:

1.1-Tübşin: Tübşin'nin oğulları: 1-Bülteçer, 2-Sarat, 3-Boralçi, 4-Bektey.

1.2-Tekşi: Tekşi'nin oğulları burada da verilmemiştir.

1.3-Jahutu: Jahutu'nun oğulları: 1-Töre Timur, 2-Mübarek, 3-Tokta.

1.4-Sayın Buka: Sayın Buka'nın oğulları: 1-Daşman, 2-i̇lahudar.

Sayın Buka'nın kızları: 1-Neküday, 2-Taniguy, 3-Tulun. 
2-Amkiratay'ın oğulları:

\section{1-Tok Temür}

2.2-Tokukacı (Muizzü'l-Ensab, vr. 48)

Görüldüğü üzere Muizzü'l-Ensab ile Reşîüüddin'in eseri birçok noktada birleşmekte, Muizz listeyi biraz daha genişletmektedir. Biz Câmiu't-Tevârîh'i başta Moğol kaynakları ve Çin kaynaklarına dayandığından dolayı esas almakta ancak Muizzü'l-Ensab'ın eklediği bilgileri de önemli bulmaktayız zira Şu'b-1 Pencgâne'de de rastlanan Amkiratay ismi diğer eserlerden biraz farklı olarak Möge'nin torunu olarak gösterilmiştir. (Khamidova, 2017, s. 861)

\subsubsection{Möge}

Nayman kökenli Saruk Hatun'tan doğan Möge, Toluy'un sekizinci oğludur. (Khamidova, 2017, s. 861; Muizzü'1-Ensab, vr. 48) Kaynaklardan anlaşıldığına göre Möge, Mengü Han'a en yakın ve sadık kardeşlerinden biridir. Mengü'nün iktidar olduğu 1251 kurultayında onun en büyük destekçilerinden biri olan Möge, anlaşıldığı üzere Mengü'nün tahta çıkış sürecinde büyük çaba sarf etmiş ve çeşitli propagandalarda bulunmuştur. Zira o 1251 yılında yapılan kurultay sırasında, görüşmeler bir hayli heyecanlı iken ağabeyi Mengü'nün iktidar gelmek konusundaki tereddütlerinden dolayı ayağa kalkarak konuşma yapmıştır. Möge konuşmasında: “Burada toplanmadan önce hepimiz Batu Kaan'ın emrinden çıkmamak, onun gösterdiği yoldan sapmamak ve onun dediklerini aynen uygulamak konularında senet imzaladık. Fakat şimdi Mengü Kaan'ın alınan kararı bozduğu ve verdiği sözden döndüğü görülmektedir. Eğer burada bulunan büyük küçük herkes daha önce verilmiş olan kararda ısrar ederse, Mengü Kaan'ın ona itiraz etmeye ve karşı gelmeye gücü yetmez" diyerek kurultayda bulunan herkesin Sayın Han'ın (Yuvalı, 1994, s. 107) kararı uyarınca Mengü'yü tahta çıkarmalarını ve bağlılık yemini etmelerini talep etmiştir. (Cüveyî, 2013, s. 462) Möge bununla birlikte kurultay sonrası ağabeyini ortadan kaldırmak isteyen Ögedey Ulusundan Şiremön'ü yakalayan ordunun başına komutan olarak getirilmiştir. (Reşîdüddin/Boyle, 1971, s. 202-209) Mengü Han'dan sonra Kubilay'a bağlandığı ve onun sadık adamlarından biri olduğunu anladığımız Möge, Kubilay Han ile birlikte Songlar üzerine yapılan bir sefer sırasında, 1260 'lı yıllarda öldüğü sanılmaktadır. Nitekim kayıtlara göre Möge, 1259 yılında Kubilay ve Moğol ordusunun Yangze boylarında Songlar üzerine yapılan giriştiği harekâtta görevlidir. Möge, Kubilay Han'a o sıralar meydana gelen Mengü'nün ölümünü haber vererek seferi durdurmasını ve cenazeye katılmasını tavsiye etmiştir. Kubilay Möge'nin geri dönüş tavsiyesine uymayarak ilerlemeye devam etmiştir. Bu noktadan itibaren Möge ile ilgili herhangi bir bilgiye rastlanmamaktadır. (Rossabi, 2015, s. 46-47; Reşîdüddin/Boyle, 1971, s. 241251)

Reşîüddin'in Şu'b-ı Pencgâne adlı eserine göre onun yalnızca Çingtüm adlı bir oğlu olmuştur ve şeceresi şu şekildedir:

1-Çingtüm: Çingtüm'ün oğulları: 1-Kazan, 2-Hıtay, 3-Kükeday, 4-Şirin.

Çingtüm'ün kızları: 1-Kumakan, 2-Şirin, 3-Ebügen, 4-Taştemür, Polat. (Khamidova, 2017, s. 862)

Muizzü'l-Ensab'a göre ise Taştemür, Ebügen, Polat ve Çingtüm adında dört oğlu olmuştur ve şecereleri şu şekildedir:

1-Taştemür

2-Ebügen

3-Polat

4-Çingtüm: Çingtüm'ün oğulları: 1-Şirin, 2-Kazan, 3-Hıtay, 4- Kükeday:

Çingtüm'ün kızları: 1-Kumakan, 2-Şirin. (Muizzü'l-Ensab, vr. 48) 
Bununla beraber Reşîudüddin'in diğer eseri Câmi'ut-Tevârîh'in Cengiz oğullarını anlattığı ikinci cildinde Möge ile ilgili: "İki oğula sahipti: İlki Çingtüm ikincisi Ebügen." demektedir. (Reşî̉üddin/Boyle, 1971, s. 162) Biz Reşîdüddin'in Şu'b-1 Pencgâne adlı eserinde verdiği listeyi daha Reşîüddin'in adı geçen döneme Muizzü'l-Ensab'ın yazıldığı dönemden bir buçuk asır daha yakın olmasından ötürü muteber bulmaktayız.

Möge, Mengü Han ve Moğollar için kıymetli bir şahsiyettir. 1251 yılında birçok soruna gebe olarak düzenlenen kurultayda ağabeyi Mengü'nün han olması için yaptığı konuşma orada bulunan birçok prensi etkilemiş̧ir. Sonrasında yaşanan iktidar darbesi girişiminin engellenmesi ve faillerin tutuklanması görevini üstlenen ekibin başında yine Möge vardır. Bu bakımdan Möge, Mengü Han'a yardımı ve dolayısıyla Moğol iç siyasetine bulunduğu katkıları açısından etkili bir şahsiyettir. Dahası soyundan gelenler ataları Möge gibi Kubilay taraftarı hizipte yaşamlarına devam etmiş olmalılardır. Zira Kubilay aleyhine düzenlenen 1260 ve 1270-75 olaylarında muhalifler arasında adları geçmemektedir.

\subsubsection{Sögötü}

Hangi hatundan doğduğu bilinmeyen Sögötü, Toluy'un dokuzuncu oğludur ve ne zaman doğduğu bilinmemektedir. Sögötü'nün askerlik mesleğiyle yakın ilişki içinde olduğunu 1219'da İslam ülkeleri üzerine yapılan seferde görev alması ve burada Alak Noyan ve Tokay ile beraber Fenaket'in ele geçirilmesi hadisesinde bulunmasından anlamaktayız. (Cüveynî, 2013, s. 125) Bununla birlikte Sögötü, Mengü Han tarafından 1253 İran seferi için ağabeyi Hülagü'nün hizmetine tahsis edilmiştir. Ancak Sögötü, Hülâgû ile İran yolunda, henüz Semerkant civarlarına gelindiği sıralarda ölmüştür. (Khamidova, 2017, s. 862; Cüveynî, 2013, s. 501) Muizzü’l-Ensab’a göre bir oğlu ve bir kızı vardır. Kızının adı Tuday oğlunun adı Tok Temür'dür. Tok Temür'ün Togan adlı bir oğlu vardır. (Muizzü'l-Ensab, vr. 48) Reşîdüddin'in Şu'b-ı Pencgâne adlı eserine göre Sögötü'nün Tok Temür adlı bir oğlu vardır. Tok Temür'ün ise Tuday adında bir kızı Togan adında bir oğlu vardır. Togan'ın ise Kadgasun isimli bir oğlu olduğu anlaşılmaktadır. (Khamidova, 2017, s. 862) Tok Temür hakkında birçok şey rivayet eden Reşî̉üddin, Tok Temür'ü çok iyi bir okçu ve çok cesur bir adam olarak nitelendirirken katıldığı savaşlarda sürekli gri renkte at sürdüğünü zikretmektedir. (Reşîdüddin/Boyle, 1971, s. 162) Yazara göre Tok Temür gri renkte at kullanmasının sebebini şöyle açıklamaktadır: "İnsanlar kanları üzerinde görünmesin ve düşmanlarını cesaretlendirmesin diye çeşitli renklerde atlar ve doru atlar seçerler. Bana gelince ben gri at seçerim çünkü tıpkı kırmızının kadının süsü olduğu gibi süvarinin ve atının üzerindeki yaradan çıan kanın erkeğin elbisesine ve atın bacaklarına damlaması ve uzaktan görülmesi erkeklerin ziyneti ve süsüdür." (Reşîüuddin/Boyle, 1971, s. 162) Yazarımız onun bu denli cesur olmasının aklını isyan fikirleriyle doldurduğundan bahsetmektedir. (Reşîdüddin/Boyle, 1971, s. 162) Nitekim Cengizli aileleri arasındaki çatışmalar 1260 'l y ylların sonundan itibaren şiddetlenmekte ve Arık'ın ölümünün ardından yeni isyanlar tertiplenmektedir. Kubilay muhaliflerinden olan Tok Temür, Kubilay Han'ın oğlu Nomoghan ve Kökücü'yü Deresü seferindeyken ordu içi anlaşmazlıklardan faydalanarak ele geçirmiştir. Kubilay'ın baş hatunu Çabi'den doğan Nomoghan, babası tarafından önce 1271'de Çağatay ve Ögedey Ulusuna karşı Almalık'a gönderilmiş ancak tam anlamıyla başarılı olamamıştı. Tok Temür'ün onu ele geçirmesi hadisesi babası tarafından $1275^{\prime}$ de Kaydu'nun üzerine tekrar gönderilmesi ile yaşanmıştır. Tok Temür sefer esnasında Nomoghan ordusundaki prenslerin ve komutanların aralarındaki hizipçilikten faydalanmış ve birçoklarıyla anlaşarak Nomoghan'ı, Kubilay'ın diğer oğlu Kökücü'yü ve Sağ Kanat başnazırı Antogon Noyan'ı esir almışlardır. Olayın diğer baş faili ise Şiregi'dir. (Reşîdüddin/Boyle, 1971, s. 198) Bu isyancı grubun içinde Şiregi dışında Mengü oğlu 
Ürüng Taş oğlu Sarban'da vardır. (Reşîdüddin/Boyle, 1971, s. 197) Muhaliflerin ele geçirdiği Nomoghan ve Kökücü, Cuci Ulusundan Mönge Temür'e, Antogon ise Ögedey Ulusundan Kaydu'ya gönderilmiş, Tok Temür ve yandaşları Kubilay karşıtlarından daha büyük bir isyan talebinde bulunmuşlardır. Ancak Kaydu, kendi inisiyatifi dışında gelişen bu ayaklanmaya iltifat etmeyerek Tok Temür ve Şiregi'nin isteğini geri çevirmiş bir süre sonra Antogon Noyan'ı serbest bırakmıştır. Cuci Ulusu tarafında ise Nomoghan ve Kököcü, Kelmiş Aka'nın gayretleri neticesinde rahat süren on yıllık bir esaret sonrası Kubilay'a geri gönderilmişlerdir. Tok Temür ve Şiregi'nin başını çektiği isyancılar ise Cuci ve Ögedey ailelerinden bekledikleri ilgiyi göremeyince Moğolistan'a ve Yukarı Yenisey bölgesine göçmüşlerdir. Burası onlara başkent Karakorum'a saldırmak için üs vazifesi görmüştür. Ancak bu dönemde Kubilay'ın Orta Asya'da uyguladığı ekonomik siyasetin başarılı sonuçları askeri alanda da kendini göstermiş, bölgede hava Kubilay lehine dönmüştür. Ayrıca isyancılar kendi aralarında tam anlamıyla bir birlikten de yoksundular Durumun farkında olan Kubilay isyancılara karşı fırsat kollamış ve 1279' da Tok Temür'ü Karakorum yakınlarında yenerek esir etmiştir. Kısa bir süre sonra Şiregi'de yakalanmıştır. Adı geçen Toluy soyluları çok geçmeden idam cezasına çarptırılarak öldürülmüşlerdir. 1280'li yıllarda ise Kubilay'ın temellerini sarstığı isyancı grubun diğer önderleri, Orta Asya'daki diğer Moğollar'a katıldıklarında bütün bozkırdaki baskın güç artık Kubilay olmuştur. (Rossabi, 2015, s. 104-111; Reşîdüddin/Boyle, 1971, s. 162)

Sögötü oğulları, Çağatay, Ögedey ve Cuci uluslarının içinde bulunduğu karışık ortamda kesin olarak bir hizipte yer almamışlar, daha çok iç savaşın şiddetlenmesi ve Kubilay Han'ın zor durumda kalmasını amaçlamışlardır. Birlikte hareket ettikleri Arık Böke'nin oğulları Yobukur ve Melik Temür düşünüldüğünde Tok Temür ve Şiregü'nün, 1260 olaylarında Arık Böke tarafında yer almış oldukları ve Kubilay'ın Arık'a galip gelmesini hazmedemedikleri anlaşılmaktadır. Nihayetinde onlar Kubilay'ın ordusundaki mevcut durumdan rahatsız prensleri manipüle etmişler, bu sayede Kubilay oğlu Nomoghan ve Kökücü ile mühim Yüan komutanlarından Antogon Noyan'ı ele geçirmişlerdir. Bu durum onların diğer hiziplerle askeri ve diplomatik bağlamda karşılaştırıldığında azımsanmayacak bir güce sahip olduklarını göstermektedir. Sonuç olarak Kubilay muhalifleri Kaydu ve Mengü Timur tarafından pek dikkate alınmasalar bile Yüan hanedanından üç önemli şahsiyeti ele geçirmeleri bakımından bulundukları dönemde bir hayli ses getirdikleri, Kubilay'ı çok zor bir duruma soktukları açıktır. Zira Kubilay'ın oğulları ancak on yll sonra geri dönebilmişlerdir

\subsubsection{Sübeday}

Hangi hatundan doğduğu bilinmeyen Sübedey, Toluy'un onuncu ve en küçük oğludur ve ne zaman doğduğu bilinmemektedir. Sübeday hakkında Reşîüuddin'in Şu'b-1 Pencgâne adlı eseri ve Muizzü'l-Ensab Sögötü'nün ağabeyi Mengü Han'ın yanında kaldığ1 ve hiç çocuğu olmadığ bilgisini vermişlerdir. (Muizzü'l-Ensab, vr. 48; Khamidova, 2017, s. 861) Câmiu't-Tevârîh'in de ise Reşîdüddin yalnızca ismini zikretmiş, hakkında bilgi notu düşmemiştir. (Reşîdüddin/Boyle, 1971, s. 162) Evlenip evlenmediği hakkında herhangi bir bilgimizin olmadığ1 Sübeday, Toluy'un en küçük oğlu olduğundan dolayı en azından 1227-1229 yıllarında doğsa, Mengü'nün iktidarının başlarında otuz iki - otuz dört yaşlarında, en çok ise kırk yaşlarında olmalıdır.

\subsection{Kizları}

\subsubsection{El Temür (Yantemür)}

Reşîdüddin Câmiu't-Tevârîh'in de, Toluy'un Lingkun Hatun'dan doğan El Temür adlı bir kızının olduğunu zikrederek onun Oyrat kabilesinden Törelçi Küregen'in üçüncü oğlu Pars Buka Küregen ile evlendirildiğini ifade etmiştir. (Reşîdüddin/Boyle, 1971, s. 312) El Temür'ün kocası 
Pars Buka Küregen'in Emegan adlı bir kızı Arık Böke'nin ikinci oğlu Melik Timur ile evlenmiştir. (Zhao, 2008, s. 141) İsmini tespit edemediğimiz bir oğlundan olan Tok Temür adlı torunu ise Melik Timur'un kızı Emegen ile evlenmiştir. (Zhao, 2008, s. 147) Muhtemelen bu evlilikler karşılıklı olarak aynı zamanlarda gerçekleştirilmişlerdir. Pars Buka Küregen'in ayrıca Beklemiş ve Şirap adlı iki oğlu, Kubilay'ın önemli emirlerinden olup sarayında görev almakta ve Yüan hanedanına mensup ancak isimleri bilinmeyen prenseslerle evlidirler. (Zhao, 2008, s. 133) Pars Buka'nın Arık Böke ile dünürlügü Kubilay ile yakın ilişkileri bağlamında düşünüldüğünde, Mengü iktidarı süresinde ya da ondan daha önce gerçekleşmiş olmalıdır. Nitekim Arık Böke devri ya da sonrasında Pars Buka Küregen, oğullarının evlilikleri nedeniyle Kubilay Han taraftarı hizipte yer almış ve onlara karşı mücadele etmiş olmalıdır. Onun Şirap, Beklemiş ve ismi bilinmeyen bir oğlu daha açıkça belirtilmiş olmasa bile El Temür'den doğmuş olabilirler. Zira Şirap ve Beklemiş'in Toluy kızı El Temür'den doğmaları, sıradan bir hatundan doğup Yüan sarayından kız almaları olanağından daha yüksek bir ihtimaldir. El Temür ve Pars Buka Küregen'in hakkında kaynaklarımızda daha fazla bilgi bulunmamakla beraber onlar hayatlarının büyük bir bölümünü Kubilay'ın emrinde geçirmiş olmalılardır. El Temür, George Zhao'nun Yüanşi tarihinden aktardığına göre Yantemür adı ile de bilinmektedir. (Zhao, 2008, s. 133)

\subsubsection{Yesübuha}

Yüanshi'den (Zhao, 2008, s. 131) aktarıldığına göre, Toluy'un Yesübuha adlı bir kızı daha vardır. Biz ne Reşîdüddin'in Su'b-ı Pençgâne ya da Câmiu't-Tevârîh'in de ne de Muizzü'lEnsab'ta Yesübuha adlı bir hatuna rastlamamaktayız. Yüanşi'de bahsedilen Yesübuha, Alçi'nin torunu Bulga Hatun ile evlenen Cörike'ye bir karşılık olarak, Kongirat kabilesinden Alçi Noyan'ın ikinci oğlu Voçen ile evlendirilmiştir. (Zhao, 2008, s. 211) Voçen ile Yesübuha'nın evlilikleri, Voçen'in Ögedey Han döneminde, hanedan tarafından "Wanhu" yani "Tugay Komutanı" unvanı aldığı 1238 yılında gerçekleşmiştir. Ancak aynı yıl Voçen ölünce unvanı en küçük kardeşi Naçen'e intikal etmiştir. (Zhao, 2008, s. 103) Yuanşi'de Yesübuha, Yüan saray prensesleri içinde zikredilmekte ve "Lu devletinin en yüce prensesi" lakabı ile tanınmaktadır. (Zhao, 2008, s. 115) Muhtemelen 1253-59 yıllarında Kubilay'ın yanına Çin'e intikal etmiş ve orada kalmıştır. Hakkında daha fazla bilgi bulamadığımız bu hatun muhtemelen yine 1238'den sonra Kubilay'a yakın ve önemli emirlerinden biri ile evlendirilmiş olmalıdır. Yesübuha'nın Toluy'un hangi hatunundan doğduğu bilinmemektedir.

\subsubsection{Tümügen}

Dumugan (Zhao, 2008, s. 289) ismiyle de bilinen bu hatuna Muizzü'l-Ensab ve Şu'b-1 Pencgâne adlı eserlerde tesadüf edemedik. Temügen, Zhao'nun Yüanshi adlı Çin kaynağından ve Budist bir rahibin tabletinden aktardıklarına göre "Yu Prensi" lakaplı Nükeday ile evlenmiştir. Nükeday, Cengiz Han'ın kızı Alahay Beki ile onun Öngüt kabilesinden kocası Cenku'nun oğludur. (Zhao, 2008, s. 151) Budist bir rahibin adına 1252 yılında yazılmış tablete göre Budistlerin "budist günışı̆̆ı" olarak ululadığı hatunun Öngüt kabilesinin çok önemli şahsiyetlerinden biri olduğu, sarayda ve halk üzerinde büyük bir etkisi bulunduğu ve büyük bir askeri güce sahip olduğu zikredilmektedir. (Zhao, 2008, s. 158) Öngüt kabilesinin büyük oranda Nestûrî Hıristiyan olmaları göz önüne alındığında Budist Tümügen'in Öngütler içinde bu derece baskın olması, bahsedilen dönem yani 1252'de kardeşi Mengü Han'ın Büyük Han olmasında ileri geliyor olabilir. Tümügen'in kocası Nükeday, Güney Song seferi sırasında ölmüştür. (Zhao, 2008, s. 158-159) Ondan sonra Tümügen yine Öngütlerden Çahu adlı biriyle evlenmiştir. (Zhao, 2008, s. 289) Çahu'nun kim olduğu bilinmemekle birlikte, onun Neküday'ın oğlu ya da kardeşlerinden biri olma olasılığı bir hayli yüksektir. 


\section{SONUÇ}

Toluy ve ailesi hakkında yapılan çeşitli çalışmalar ve Moğol döneminde yazılmış meşhur kaynaklar Toluy'un resmen adları bilinen altı hatunu olduğunu, bunlardan yalnızca ilk hatunu Sorgaktani Beki'nin baş hatunu sıfatı taşıdığı ve yalnızca ondan gelen çocuklarının mirasından faydalandıkları tespit edilmiştir. Buna kanıt olarak Toluy ailesinin Otçigin'i Arık Böke'nin annesi Sorgaktani Beki'nin ordosunu devralması gösterilebilir. Bunlarla beraber Toluy'un Sorgaktani'den olan dört oğlu: Mengü (Karakorum), Kubilay (Hanbalık), Hülâgû (Tebriz) ve Arık Böke (Karakorum) hükümdar sıfatı kazanmışlardır. Diğer altı oğlunun askeri görevler dışında aldıkları siyasi nitelikteki üst düzey görevleri tespit edilememektedir. Bununla birlikte onun El Temür, Yesübuha ve Tümügen adlı üç kızı mevcuttur. Toluy oğullarından Sögötü ve Kutuktu soyu dışındakilerin sülbünden gelenlerin genel anlamda Çin hizbine yakın durdukları anlaşılmakta bu bağlamda Toluy ailesinde genel olarak birlik havası görülmüştür.

Toluy ile evlenerek hanedan üyesi olan hatunların üçü Kerayit, ikisi Nayman ve biri Kongirat kabilesindendir. Hatunların hepsi çok önemli şahsiyetlerin kızları ve torunlarıdır. Bu bakımdan Toluy kadınları yönetim ve devlet idaresi kültürü ve geleneğine sahiptirler. Ayrıca Toluy hanesine Nestûrî Hıristiyanlık hakimdir. Nitekim hakkında çok az şey bilinen Nayan Hatun dışında diğer beş hatunun hepsi Hıristiyandır. Bu husus Toluy'un oğullarının dini görüşlerinde etkili olmamakla beraber sosyal bağlamda halka karşı dini ayrım gözetmeye itmiş olabileceği göz önünde bulundurulması gerekir. Ancak Toluy kadınlarının dini tutumları Toluy oğullarının dini görüşlerini etkilememiştir. Zira kızlarından ve oğullarından Budist olan ya da geleneksel anlamda Şaman inancına devam edenler görülmüştür.

\section{EXTENDED ABSTRACT}

According to the legends, Genghis's ancestor is Bodanchar, the youngest son of Alan Gua, born of Grizzly Wolf and Female Deer, and also, he is the grandson of the Taichiud Chieftain Hambukai who is descended from eight generations of Bodanchar. Genghis who was connected to the Kiyad tribe from the paternal lineage was born in 1155, under the name Temujin. Genghis Khan who grew up in difficulties after being poisoned by the enemies of his father Yisügei Ba'atur gathered all the Mongols tribes under one state with the right policies over time.

Tolui who was the ancestor of the dynasties that ruled nearly thirty years after his death Mongolia, Iran and China, were the fourth and last son born of Genghis's first and chief wife, Börte Ujin. The sources about Tolui mention regularly the Great Quriltai in 1206. Although the fact that information about his youth is almost non-existent makes his date of birth controversial, many historians agree on the year 1191. We do not know what kind of education he received in his youth due to the little information given about him in the sources. Tolui received probably an education under the supervision of his mother and father. However, Tolui who had a great reputation in the military profession was probably more likely to have had close relations with the commanders of Genghis since his childhood.

His most senior wife Sorghaghtani Beqi was the mother of four sons named Mengü, Kublai, Hülegu and Arik Bukha. In general, the Keraits influenced the Mongol Khanate; especially the Tolui's house was under a great influence. As it can be seen in later times, Kerait origin women knowing state tradition were active in many important political, administrative, and religious areas of Tolui and his lineage, and Sorghaghtani Khatun, in particular, was among the most important factors in the Tolui lineage's coming to power. Sorghaghtani who became the head of the family after Tolui's death played an active role in the Tolui's house rising to power and became a well-known female figure in the world. 
Tolui had five khatuns named Toqhus, Lingkun, Saruk, Bumur and Bayan apart from his chief khatun Sorgaktani Beki. All of these wives of Tolui had ten sons and three daughters. His sons were Möngke, Jurikeh, Qutuqtu, Kublai Khan, Hülegü, Arik Bukha, Bochak, Möge, Sögötü, Sübedai. His daughters were İle Temür (Yantiemür), Yesubuhua, Tümügen.

Whether political or not, Tolui was an influential figure who guided and changed events in his own time. His name is not mentioned in the wars in which Genghis united all Mongolia. If we assume that he was in the war since he was ten years old, he must have participated in the war in which the Keraits were defeated, and the later ones. His first battle that mentioned in sources was the Jin Campaign of 1211. Tolui who proved himself with the successful operations that he carried out with his brother-in-law Chigu in this war in which he participated at the age of about twenty would be promoted by Genghis Khan. Proving that he had superior military skills than his brothers in this expedition, Tolui would achieve greater success in 1219 Khwarazm Battle and the second Jin Battle with Ögedei Khan. Tolui died in October 1232 of a relentless disease on his way back from his Jin Battle with his older brother Ögedei Khan at the location of the separation of the Tula and Onon rivers. 


\section{KAYNAKÇA}

Abû Hayyân. (1931). Kitâb al-İdrâk li-lisân al-Atrâk (Caferoğlu, A. Çev.). İstanbul: Evkaf Matbaası. Abu'l-Farac, G. (1987). Abû'l Farac Tarihi (C. II) (Doğrul, Ö. R. Çev.). Ankara: Türk Tarih Kurumu. Albayrak, K. (2007). Nestûrîlik. İslam Ansiklopedisi, (C. 33, s. 15-17) İstanbu:l Türkiye Diyanet Vakfı Yay. Anonim. (1986). Moğollar'ın gizli tarihi I. tercüme. (Temir, A. Çev.). Ankara: Türk Tarih Kurumu Yayinları.

Atwood, C. P. (2004). Encyclopedia of Mongolia and the Mongol Empire. New York: Fact On File, Inc.

Akkuş, M. (2020). Moğollarda din ve siyaset İlhanlı hanlarının dini kişiliği ve uygulamaları. Konya: Çizgi Kitabevi.

Boyle, J. A. (1956). On The Titles given in Juvaini to certain Mongol princes. H. J. A. S., XI, X, 146-154.

Buell, P. D. (2003). Historical dictionary of the Mongol world empire. Lanham, Maryland and Oxford: The Scarecrow Press.

Cahun, L. (2006). Asya tarihine giriş, kökenlerden 1405'e Türkler ve Moğollar (Kaya, S. İ. Çev.). İstanbul: Seç Yayın Dağıtım.

Cüveynî, A. M. (2013). Tarih-i Cihan Güşa (Öztürk, M. Çev.). Ankara: Türk Tarih Kurumu Yayınları.

Çulha, T. (2006). Karaycanın kısa söz varlı̆̆ı, Karayca-Türkçe sözlük. İstanbul: Dil ve Edebiyat Dizisi.

d'Ohhson, A. K. (2008). Moğol tarihi, denizler imparatoru (Apaydın, C. B. Çev.). İstanbul: Nesnel Yay.

Delibalta, Y. (2019). Karahıtay Devleti'nin inhitatı ve Nayman Veliahtı Küçlük'ün Doğu Türkistan tahakkümü. Bayburt Üniversitesi Insan ve Toplum Bilimleri Fakültesi Dergisi, 2/4, 33-54.

Durak, N. (2008). Çingizli hatunları I: Sorgaktani Beki. Turkish Studiest 3/1, 251-258.

Ebu'l Gazi Bahadır Han. (2009). Türk'ün soy ă̆acı Türk şeceresi (Yiğit, Y., Sad.). İstanbul: İlgi Kültür Sanat.

Grousset, R. (1996). Bozkır imparatorluğu, Atilla, Cengiz Han, Timur (Uzmen, M. R. Çev.). İstanbul: Ötüken Yayınları.

Hope, M. (2016). Power, politics and tradition in the Mongol Empire and the Ilkhanate of Iran. Oxford (UK): Oxford University Press.

Jackson, P. (2017). The Mongols and The Islamic world, from conquest to conversion. Liandysul (UK). Yale University Press.

Kafalı, M. (1993). Cengiz Han. İslam Ansiklopedisi (C. 7, s. 367-369). İstanbul: Türkiye Diyanet Vakfı Yay.

Kafalı, M. (1993). Cuci Han. İslam Ansiklopedisi (C. 8, s. 78-79). İstanbul: Türkiye Diyanet Vakfı Yay.

Kafalı, M. (2005). Çă̆atay Hanlığı (1227-1345). Ankara: Berikan Yayınevi.

Kafesoğlu, İ. (1998). Türk milli kültürü. İstanbul: Ötüken Yayınları.

Khamidova, C. I. (2017). Рашид Ад-Дин. Шуаб-И Панджгана. 2. Монгоды И Тюрки (3) *. Золотоординкое Обозрение. Т. 5/4, 846-865.

Lessing, F. D. (1960). Mongolian-English dictionary. Berkeley and Los Angeles: University of California Press.

Manz, B. F. (2011). The rule of the infidels: the Mongols and Islamic word. The New Cambridge History of Islam Volume:3 The Eastern Islamic World Eleventh to Eighteenth Centuries, David O. Morgan \& Anthony Reid (Eds.). England (Cambridge): Cambridge University Press, 128-168.

Monte Crucis. (2018). Ricoldus de, doğu seyahatnamesi, bir Dominikan keşiş'in Anadolu ve Ortadoğu yolculuğu ( Altunbaş, A. D. Çev.). İstanbul: Kronik Yay.

Muizzü'l Ensab. Bibliotheque Nationale Paris, Department Des Manuscrits, Persian 67.

Özaydın, A. (1991). Aynicâlût savaşı. İslam Ansiklopedisi (C. 4, s. 275-276). İstanbul: Türkiye Diyanet Vakfi Yay.

Özgüdenli, O. G. (2005). Moğollar. İslam Ansiklopedisi (C. 30, s. 225-229). İstanbul: Türkiye Diyanet Vakfı Yay.

Özgüdenli, O. G. (2006). Karakorum. İslam Ansiklopedisi (C. Ek-2, s. 22-23). İstanbul: Türkiye Diyanet Vakfı Yay.

Özgüdenli, O. G.-Prazniak, R. (2016). Kubilay Kağan. İslam Ansiklopedisi (C. EK-2, 88-89). İstanbul: Türkiye Diyanet Vakfı Yay.

Polo, M. (2019). Dünyanın hikâye edilişi, harikalar kitabı. (Ergüden I. \& İlkgelen, Z. Z.,Çev.), İstanbul: Ötüken Yayınevi,.

Reşî̀düddin Fazlullah Hemadanî. (1971). The Successors of Genghis Khan. (Boyle J., Trans.), New York and London: Columbia University Press. 
Reşî̉üddin Fazlullah Hemedanî. (2013). Câmiu't-Tevârih (İlhanlılar kısmı) (Aka, İ., Ersan, M. \& Khelejani, A., Çev.). Ankara: T.T.K.

Rossabi, M. (2015). Kubilay Han. (Özol, Ö. Çev.). İstanbul: Türkiye İş Bankası Yayınları.

Rubruk, W. (2019). Moğollar'ın Büyük Hanı'na seyahat, 13. yüzyılda İstanbul'dan Karakorum'a yolculuk. (Ayan, E. Çev.). İstanbul: Kronik Kitap.

Spuler, B. (1957). İran Moğollar'ı siyaset, idare ve kültür İlhanlılar devri (1220-1350). Ankara: Türk Tarih Kurumu.

Taşağıl, A. (2001). Karahıtaylar. İslam Ansiklopedisi (C. 24, s. 415-416). İstanbul: Türkiye Diyanet Vakfı Yay.

Taşağıl, A. (2015). Hanbalık. İslam Ansiklopedisi (C. 15, s. 524-525). İstanbul: Türkiye Diyanet Vakfı Yay. Tiesenhausen, W. (1941). Altın Ordu Devleti tarihine ait metinler. İstanbul: Maarif Matbaası.

Togan, Z. V. Çengiz Han (1155-1227). 1969-1970 Dönemi Ders Notları, 36.

Vladimirtsov, B. Y. (1995). Moğollar'ın içtimâ̂ teşkilâtı, Moğol göçebe feodalizmi. Ankara: Türk Tarih Kurumu.

Yuvalı, A. (1994). İhanlılar tarihi I. kuruluş devri. Kayseri: Erciyes Üniversitesi Yayınları.

Yuvalı, A. (1998). Hülâgû. İslam Ansiklopedisi (C. 18, s. 473-475). İstanbul: Türkiye Diyanet Vakfı Yay.

Yuvalı, A. (2000). İlhanlılar. İslam Ansiklopedisi (C. 22, s. 102-105). İstanbul: Türkiye Diyanet Vakfı Yay.

Zhao, G. Q. (2008). Marriage as political strategy and cultural expression, Mongolian royal marriages from world empire to Yuan Dynasty. New York: Peter Lang Publishing. 